\title{
Pemanfaatan Aplikasi TIK-TOK di Masa Pandemi Covid-19
}

\author{
Bayu Giri Parameswara1, Luli Nurul Liyah ${ }^{2}$, Nita Sania ${ }^{3}$, Agim Ibrahim ${ }^{4}$ \\ Program Study IImu Komunikasi, Fakultas IImu Komunikasi, Universitas Islam Nusantara
}

\begin{tabular}{|c|c|}
\hline ARTICLE INFO & ABSTRACT \\
\hline Article history: & \multirow{4}{*}{$\begin{array}{l}\text { The purpose of this study is as a tool to find out the phenomenon of } \\
\text { Tiktok application users in the midst of the Covid-19 pandemic, how } \\
\text { the motives of Tiktok application users are, the actions of Tiktok } \\
\text { application users and what is the meaning of using the Tiktok } \\
\text { application in the midst of the Covid-19 pandemic. The research } \\
\text { methods and methods that have been used by researchers in } \\
\text { conducting this research are the Phenomenological method, with } \\
\text { the type of qualitative research, and the data collection technique of } \\
\text { research results is done by means of online interviews. The } \\
\text { interviews conducted involved several users of the Tiktok application } \\
\text { itself. Based on the results of the study, it was obtained that the } \\
\text { motive for using the Tiktok application in the midst of the Covid-19 } \\
\text { pandemic was as an entertainment medium. Next, the actions of } \\
\text { Tiktok application users to express their creativity. }\end{array}$} \\
\hline $\begin{array}{r}\text { Received Jun 9, } 2021 \\
\text { Revised Nov 20, } 2021 \\
\text { Accepted Nov 28, } 2021\end{array}$ & \\
\hline \multirow{4}{*}{$\begin{array}{r}\text { Keywords: } \\
\text { TIK-TOK; } \\
\text { Masa Pandemi; } \\
\text { Covid-19. }\end{array}$} & \\
\hline & \\
\hline & ABSTRAK \\
\hline & $\begin{array}{l}\text { Tujuan dari penelitian ini yaitu sebagai alat untuk mengetahui } \\
\text { fenomena dari pengguna aplikasi Tiktok ditengah pandemi Covid- } \\
\text { 19, bagaimana motif pengguna aplikasi Tiktok, tindakan pengguna } \\
\text { aplikasi Tiktok serta bagaimana makna penggunaan aplikasi Tiktok } \\
\text { ditengah pandemi Covid-19. Metode dan cara penelitian yang telah } \\
\text { digunakan peneliti dalam melakukan penelitian ini adalah metode } \\
\text { Fenomenologi, dengan jenis penelitian kualitatif, dan teknik } \\
\text { pengumpulan data hasil penelitian dilakukan dengan cara } \\
\text { wawancara secara online. Wawancara yang dilakukan melibatkan } \\
\text { beberapa pengguna aplikasi Tiktok itu sendiri. Berdasarkan hasil } \\
\text { penelitain, diperoleh gambaran bahwa motif pengguna aplikasi } \\
\text { Tiktok ditengah pandemi Covid-19 ialah sebagai media hiburan. } \\
\text { Selanjutnya, tindakan pengguna aplikasi Tiktok untuk } \\
\text { mengekspresikan kreativitasnya. }\end{array}$ \\
\hline
\end{tabular}

This is an open access article under the CC BY-NC license.

Corresponding Author:

Bayu Giri Parameswara

Program Study IImu Komunikasi, Fakultas IImu Komunikasi,

Universitas Islam Nusantara,

Jl. Soekarno-Hatta No.530, Sekejati, Kota Bandung, Jawa Barat 40286

Emaill: kandank.studio@gmail.com

\section{PENDAHULUAN}

Qiyang \& Jung (2019) menjelaskan bahwa media sosial memfasilitasi dalam membuat dan membagikan pengetahuan antar orang yang memiliki kemiripan dalam tujuan dan perilaku. Interaksi serta pertukaran informasi tersebut yang menjadi motivasi seseorang Menggunakan media sosial. Berkaitan dengan ini, masyarakat menggunakan media sosial untuk dapat berinteraksi, bertukar informasi, serta terutama mengisi kegiatan sehari-hari dirumah.

Dalam perkembangan teknologi sekarang, salah satu aplikasi yang paling menonjol yang sangat populer di kalangan anak-anak maupun remaja adalah aplikasi tiktok. Sebuah aplikasi 
sinkronisasi bibir (lipsynch) itu telah diunduh lebih dari 50 juta pengguna di google play. Berdasarkan fakta yang penulis lakukan di lapangan terdapat video di media sosial Instagram yang memperlihatkan remaja merekam dirinya menggunakan aplikasi tiktok dengan mengumbar aurat saat bergoyang dan sedang menggunakan seragam sekolah. Sehingga dapat menarik perhatian orang lain yang menonton, sampai melakukan tindakan asusila yang tidak pantas di konsumsi anak remaja. Semua itu dari bentuk penggunaan aplikasi tiktok yangberlebihan dan merupakan salah satu dari gangguan kepribadian remaja sekarang, atau lebih di kenal dengan istilah narsisme. (Winarno, 2018)

Indonesia saat ini berdasarkan hasil studi Polling Indonesia yang bekerjasama dengan Asosiasi Penyelenggara Jasa Internet Indonesia (APJII) mendapatkan bahwa sebanyak 171,17 juta jiwa atau bila dipersentasekan sekitar $64,8 \%$ penduduk Indonesia merupakan pengguna Internet. Angka yang sangat besar ini tentunya membuat masyarakat Indonesia mengalami perubahan budaya dalam bermedia saat ini, karena tentunya terdapat peralatan dan prosedur baru yang akan diadaptasi oleh masyarakat itu sendiri dalam penggunaanya.

Aplikasi tiktok adalah aplikasi yang memberikan special effect unik dan menarik yang dapat digunakan oleh pengguna dengan mudah sehingga dapat membuat video pendek dengan hasil yang keren serta dapat dipamerkan kepada temen-temen atau pengguna lainnya. Dengan adanya aplikasi tiktok ini semua orang termasuk siswa bisa mengekspresikan gaya yang sesuai dengan keinginannya untuk menjadi penguna yang terlihat unik di mata oranglain. Banyk cara yang dilakukan oleh pengguna aplikasi tiktok itu guna berlomba-lomba untuk menjadi artis terkenal demi kepopuleran semata. (Susilowati, 2018:180)

Kini Tiktok menjadi trend baru di Indonesia, konten yang dihasilkan oleh pengguna Tik Tok sendiri sangat beragam. Dengan memanfaatkan situasi saat ini, pengguna Tik Tok banyak yang menggunakan aplikasi ini sebagai media edukasi Covid-19 dengan sajian yang menarik membuat khalayak tidak bosan untuk melihat konten tersebut. Untuk mengurangi dampak dan memutus mata rantai penyebaran Covid-19. Pemerintah, tenaga kesehatan bahkan masyarakat bersama-sama membuat konten edukasi dengan menggunakan aplikasi Tiktok yang mana secara tidak langsung memberikan edukasi para viewers Tiktok.

Yang mana kasus positif dan meninggal akibat Covid-19 di Indonesia semakin hari semakin bertambah dan jumlahnya pun tidak sedikit, dilansir dari website resmi covid19.go.id terhitung pada tanggal 15-02-2021 terdapat kasus positif berjumlah 1.223.930, total sembuh 1.032.065, dan meninggal 33.367. Naiknya kasus positif akibat Covid-19 merupakan masalah bersama, yang mana cara-cara edukasi dilakukan bahkan menggunakan media yang sedang trend di Indonesia, yaitu Tiktok. Penelitian ini berupaya untuk menganalisis atau melihat bagaimana penggunaan Tiktok sebagai media edukasi Covid-19 di masa pandemi.

Perkembangan tiktok pada tahun 2017 yang masuk di indonsia, lalu pada tahuh 2018 diblokir oleh kominfo dan di 2020 kini menjadi suatu budaya populer di indonesia. Budaya populer sendiri dapat dilihat dalam 4 konteks, yakni merupakan suatu budaya yang dibangun atas kesenangan yang tidak substansial dan meringankan oang dari rasa jenuh bekerja sepanjang hari , budaya populer mnghancurkan bdaya tradisional, budaya menjadi masalah dalam perspekti ekonomi, budaya dan budaya populer marx yang menetes dari atas (Bungin, 2011).

Dua tahun dari tik tok diblokir oleh kementrian informasi dan informatika, kini tiktok menjdi tren baru dan budaya populer di Indonesia. Budaya populer merpakan budaya yang disukai oleh banyak orang dan terikat dengan kelas sosial trtentu, budaya populer saat ini semakin besar dampaknya di era digital saat ini, karena kemudahana akses ke informasi memiliki dampak signifikan pada budaya populer yang ada di suatau negara (Sorrels, 2015).

Budaya populr sangat erat kaitannya dengan budaya massa, karena budaya massa bisa juga disebut budaya populer yang di hasilkan melalui teknik-teknik industri produksi massa dan dipasarkan untuk mendapat keuntungan dari khalayak konsumen masssa. Budaya massa sendiri berkembang karena semakin pedatnya teknologi dan era konvergensi yang semakin nyata. Pada dekade sebelumnya media massa menjadi bagian dari budaya populer dengan beragam keunikannya serta fenomena kehadirannnya yang tidak bisa diduga sebelumnya. (Irwanto, 2017) 
Budaya populer sendiri memiliki karakteristik, yakni budaya bpopuler yang menciptakan tren, memiliki bentuk yang seragam, dapat beradaftasi dengan baik sehingga mampu dinikmati oleh publik secara luas, bersifat sementara atau dapat diganti ketika trjadi masyarakat umum terganggu dengan produk budaya populer lainnya, daya tahanya mengikuti waktu selera publik, profotabilitas atau potensi keuntungan yang dapat oleh pihak-pihsk terkait, pola terkait, pola konsumsi dan efek budaya populer yang dapat menghasilkan kesenangan dan gangguan (Mahanani, 2015).

Menurut Omar \& Dequan (2020), terdapat beberapa motivasi seseorang menggunakan aplikasi TikTok. Pertama, ingin berinteraksi. Interaksi sosial melalui TikTok didukung dengan beberapa fitur seperti follow, comment, like, share, upload dan duet. Duet merupakan fitur yang tidak ada di sebagian besar media sosial. Fitur ini memberikan akses kepada pengguna untuk dapat melakukan video bersama dengan penguin lainnya. Kedua, archiving atau menyimpan memori.

Berdasarkan penelitian Omar \& Deequan, hal ini yang paling menonjol dalam motivasi seseorang dalam menggunakan TikTok. Hal ini didukung denganfitur save video atau "menyimpan video" yang kembali lagi, menjadi keunggulan TikTok. Ketiga, selfexpression atau pengekspresian diri. Melalui TikTok seseorang dapat mengekspresikan dirinya secara kreatif melalui video-video yang dibuat. Didukung dengan data dari GlobalWeblndex, 55\% pengguna TikTok pernah mengunggah video di laman tersebut.

Menurut Wiederhold (2020) alasan seseorang menggunakan media social saat masa pandemi atau dalam penerapan social distancing adalah information seeking atau mencari informasi serta entertainment atau hiburan. Dari alasan tersebut, dapat diartikan bahwa penggunaan media sosial TikTok pada masa pandemic guna memberi hiburan serta mencari informasi.

Apa yang ditawarkan oleh tiktok? Seperti yang sudah dikatakan sebelumnya, terjadi peningkatan penggunaan TikTok di beberapa negara termasuk di Indonesia saat masa pandemi. Lantas apa yang menarik dari aplikasi ini sehingga orang-orang narasumber, ketiganya menunjukkan perbedaan dalam waktu pengunduhan.

Salah satu narasumber mengunduh aplikasi TikTok baru-baru ini (saat masa pandemi), hal ini menurutnya disebabkan karena waktu yang lebih bebas dan tidak sibuk. Sementara, salah satu narasumber pernah mengunduh beberapa tahun lalu namun baru diunduh kembali. Narasumber terakhir, sudah mengunduh sejak lama, namun intensitas penggunaannya mengalami peningkatan. Dari hal tersebut dapat disimpulkan bahwa masa pandemi serta kebijakan dalam melakukan pembatasan social berdampak pada penggunaan TikTok.

\section{METODE PENELITIAN}

Metode penelitian yang digunakan pada studi ini adalah metode kualitatif. Menurut Lexy, J, meleong 2006 Metode kualitatif sebagai prosedur penelitian yang menghasilkan data deskriptif berupa kata-kata tertulis atau lisan dari orang-orang atau perilaku yang dapat diamati. Menurut Supardi 2006 Penelitian deskriptif adalah suatu metode penelitian yang menggambarkan semua data atau keadaan subjek atau objek penelitian kemudian dianalisis dan dibandingkan berdasarkan kenyataan yang sedang berlangsung pada saat ini dan selanjutnya mencoba untuk memberikan pemecahan masalahnya dan dapat memberikan informasi yang mutakhir sehingga bermanfaat bagi perkembangan ilmu pengetahuan serta lebih banyak dapat diterapkan pada berbagai masalah.

Lokasi dalam penelitian ini adalah negara Indonesia dimana tiktok menjadi viral, karena banyak sekali konten challange pada saat itu, karena negara Indonesia mengalami lockdown dan pada saat itu banyak sekali konten-konten untuk menghibur orang lain maupun diri sendiri dengan menonton Vidio dan men-share Vidio dengan mendapatkan penghasilan. Tempat penelitian dilihat secara online, banyak sekali teman, sahabat, ataupun keluarga menghabiskan waktu mereka dengan melihat berbagai konten. Obyek penelitian karena nampak masyarakat Indonesia menarik bagi peneliti untuk mengadakan penelitian dengan pertimbangan sebagai berikut: (a). Untuk melindungi anak-anak dibawah 17 tahun agar selau diawasi orang tuanya. (b). Adanya 
perlindungan UU ITE terhadap konten. (c). Adanya dukungan dari berbagai sumber agar kebudayaan Indonesia bisa dikenal oleh masyarakat luar dengan budaya-budaya yang ditampilkan dari konten tersebut. (d). Masyarakat yang bisa menghasilkan uang dari aplikasi tiktok tersebut dengan melakukan berbagai cara seperti, iklan, jualan, endors dsb.

Sesuai dengan jenis penelitian yang peniliti lakukan, untuk memperoleh data sebanyak mungkin dan mendalam selama kegiatan penelitian dalam penelitian kualitatif, peneliti dengan segenap kelompok merupakan kepentingan. Dengan kata lain kehadiran peneliti sangat diperlukan untuk mengkaji lebih mendalam tentang rumusan masalah yang dibahas. Peneliti akan melakukan observasi melalui media online dan melakukan wawancara secara online pada orang orang yang aplikasi tiktok di masa pandemi ini. peneliti akan mengamati dari hasil jawaban para pengguna aplikasi tiktok.

Dengan demikian dapat menyimpulkan data dari gabungan hasil wawancara dan pengamatan secara daring tersebut. Untuk mendukung pengumpulan data dari sumber yang ada, peneliti memanfaatkan buku tulis dan bolpoin sebagai pencatat data. Peneliti sebagai instrumen kunci berusaha memperoleh data tentang kesiapan, pelaksanaan, kendala, hambatan dan strategi menghadapi kendala atau hambatan tersebut sesuai dengan kenyataan yang ada di virtual online, agar informasi yang dikumpulkan benar-benar relevan dan terjamin keabsahannya. Penelitian ini dilaksanakan mulai tanggal 10 juni 2021 sampai dengan 12 juni 2021 Peran sebagai instrumen sekaligus sebagai pengumpul data, penulis realisasikan dengan mewawancarai untuk mendapatkan data tentang pemanfaatan aplikasi tiktok dimasa pandemic.

Sumber data menurut Suharsimi Arikunto:2006 adalah subjek dari mana data itu diperoleh. Sumber data meliputi dua jenis : pertama sumber data primer, yaitu data yang diambil dari sumber pertama yang ada di lapangan. Atau data yang diperoleh langsung dari objek penelitian yang berasal dari observasi dan juga wawancara, dalam penelitian ini data primer diperoleh peneliti dari aplikasi yang digemari dan banyak di instal oleh masyarakat Indonesia dalam mengikuti tren di zaman modern ini. Dan data yang kedua data sekunder, yaitu data dan situssitus internet yang berisi banyaknya aplikasi tiktok di unduh di negara Indonesia ini.

\section{HASIL DAN PEMBAHASAN}

Tujuan dari penelitian ini adalah untuk mengetahui bagaimana Pemanfaatan Aplikasi Tik-Tok Di Masa Pandemi Covid-19. Data yang dikumpulkan sebagian besar mencakup pandangan, persepsi, dan pengalaman para pemangku kepentingan melalui Focus Group Discussion (FGD). Yang terdiri dari informasi sukarela oleh 3 pria dan 1 wanita sebagai peserta FGD (tabel 1). Analisis data yang dikumpulkan mengikuti proses dua langkah. Pertama, transkrip yang menyertainya masing-masing dibaca beberapa kali. Kemudian, kedua menghadirkan kedua perberdaan dan kesamaan pandangan yang diungkapkan oleh semua pemangku kepentingan, lalu merinci sudut pandang spesifik pada setiap pemangku kepentingan.

Tabel 1. Peserta Focus Group Discussion (FGD)

\begin{tabular}{lccl}
\hline \multicolumn{1}{c}{ Partisipan } & Jenis Kelamin & Umur & \multicolumn{1}{c}{ Pekerjaan } \\
\hline Rian & $\mathrm{L}$ & 34 & Produser Program JMN \\
Nuriskika & $\mathrm{P}$ & 22 & Mahasiswi \\
Solahudin & $\mathrm{L}$ & 26 & Konten Creator \\
Arif & $\mathrm{L}$ & 26 & Digital Marketing \\
Sidik Permana & $\mathrm{L}$ & 23 & Mahasiswa \\
\hline
\end{tabular}

Dari hasil FGD, semua peserta sepakan bahwa aplikasi TikTok memiliki dampak yang sangat signifikan dimasa pandemi Covid-19, terutama saat 1 semester awal pandemi ini hadir. Dari hasil FGD dijelaskan bahwa pengaruh aplikasi TikTok secara keseluruhan berpotensi menghadirkan peluang dan tantangan baru dibidang media sosial. Rian dari JMN menegaskan "Bahkan kami kalau mau merekrut calon host juga bertanya memiliki akun TikTok gak? Lalu apakah terbiasa menggunakan aplikasi tersebut. Mengapa begitu, saya rasa TikTok sudah mulai menjadi platform yang di pertimbangkan oleh pemangku media saat ini untuk sarana promosi program mereka" Menurut Nuriskika, Mahasiswi salah satu perguruan tinggi di Bandung 
mengatakan, TikTok saat ini bukan hanya sebagai aplikasi hiburan saja, namun aplikasi ini juga dapat difungsikan sebagai tempat mengumpulkan tugas untuk beberapa mata kuliah dibeberapa jurusan.

Sedangkan Solahudin, seorang konten creator dan redaktur di salah satu media mengatakan saat ini TikTok sangat bermanfaat untuk media promosi konten, bahkan lebih efektif dari aplikasi lain yang serupa.

\section{KESIMPULAN}

Pembatasan aktivitas diluar rumah saat masa pandemi virus corona meningkatkan penggunaan internet dan media sosial terlebih lagi penggunaan terhadap aplikasi media short video yaitu TikTok. Peningkatan tersebut didasari oleh 3 motivasi yaitu berinteraksi, menyimpan memori atau archiving, dan sebagai bentuk pengekspresian diri melalui video-video yang dibuat atau self expression. Tidak hanya ketiga itu, ada salah satu motivasi paling utama narasumber dalam pengunduhan aplikasi TikTok yaitu mengikuti hal yang sedang populer saat ini (dalam hal ini: TikTok).

Para pengguna TikTok mendapatkan 3 kategori yaitu konten hiburan seperti video-video lucu atau humoris, video kesenian ataupun video berisikan tips-tips. Kemudian terdapat konten edukasi gerakan cuci tangan atau mematuhi protokol kesehatan di masa pandemi seperti ini yang berfungsi untuk memberikan bukan hanya pengetahuan namun juga keterampilan. Terakhir, konten pemasaran yang mempersuasi seseorang untuk tertarik bahkan akhirnya mencoba menggunakan hal-hal yang dipasarkan tersebut. Dalam hal ini informasi, sikap, serta opini dibentuk melalui TikTok. Namun, topik yang terkait bukanlah mengenai Covid-19 Terdapat kontenkonten yang lebih menarik perhatian, membua opini, serta sikap pengguna terhadap virus corona.

\section{Referensi}

Bogdan, R.C. dan S.K. Biklen. 1982. Qualitative Research for Education. Allyn and Bacon ,Inc. USA.

Bogdan, Robert, and Steven J. Taylor. 1975 Introduction to qualitative research methods: A phenomenological approach to the social sciences. John Wiley \& Sons,

Bungin, B. (2008). Sosiologi Komunikasi (Teori, Paradigma, dan Discourse Teknologi Komunikasi di Masyarakat). Jakarta: Kencana Prenada Media Group.

Irwanto. (2014). Studi Semiotika Sosial WEB Komunitas Kaskus Menegenai Kinerja Presiden SBY. Jurnal Komunikasi. Vol 5, No.1. Hal 16-29.

Kurniawan, B. (2018). Tik Tok Popularism and Nationalism: Rethinking National Identities and undaries on Millennial Popular Cultures in Indonesian Context. Proceedings of AICS -Social Sciences.

Mahanani, P. A. (2015). Relasi Facebook Dengan Budaya Pop Dalam Perspektif Cultural logia, 13(1), 79-88.

Soraya, I. (2017). Personal Branding Laudya Cynthia Bella Melalui Instagram (Studi Deskriptif Kualitatif Pada Akun Instagram @Bandungmakuta). Jurnal Komunikasi, 8(2).

Sorrels. (2015). Globalizing Intercultural Communication. California: Sage Publications, Inc

Susilowati. (2018). Pemanfaatan Aplikasi Tiktok Sebagai Personal Branding Di Instagram (Studi Deskriptif Kualitatif Pada Akun @bowo_allpennliebe). Jurnal Komunikasi, 9(2), 176

Yang, S., Zhao, Y., \& Ma, Y. (2019). Analysis of the Reasons and Development of Short Video Application Taking Tik Tok as an Example. 9th International Conference on Information and Social Science 